\section{Drug-Induced Enterocolitis Syndrome Due to Amoxicillin-Clavulanic Acid With Good Tolerance to Penicillin}

Freundt Serpa NP1 ${ }^{1}$, Sánchez-Morillas $\mathrm{L}^{2}$, Jaqueti Moreno $\mathrm{P}^{2}$, González-Gutiérrez $\mathrm{ML}^{1}$, Cimarra $\mathrm{M}^{1}$, Cerecedo $\mathrm{I}^{2}$, FernándezRivas $\mathrm{M}^{2}$

${ }^{1}$ Allergy Department, Hospital Clínico San Carlos, IdISSC, Madrid, Spain

${ }^{2}$ AllergyDepartment, Hospital Clínico San Carlos, IdISSC, ARADyAL RD16/0006/0009, Madrid, Spain

J Investig Allergol Clin Immunol 2020; Vol. 30(4): 301-302 doi: 10.18176/jiaci.0500

Key words: Drug-induced enterocolitis syndrome. Amoxicillin-clavulanic acid. Drug provocation test. Eosinophil cationic protein.

Palabras clave: Síndrome de enterocolitis inducida por fármacos. Amoxicilina-clavulánico. Provocación con medicamentos. Proteína catiónica del eosinófilo.

Drug-induced enterocolitis syndrome (DIES) is a non-IgEmediated hypersensitivity reaction caused by a medication. To our knowledge, there are very few reported cases, and they all involve aminopenicillins [1-5]. We report a new case with the intention of raising awareness of this clinical entity to facilitate accurate diagnosis and management.

An 18-year-old man came to our clinic with vomiting in relation to intravenous infusion of amoxicillin-clavulanic acid and metamizole during surgery for acute appendicitis when he was 9 years old. The allergological study we describe below was carried out with the written consent of the patient.

Skin prick tests (SPT) and intradermal tests (IDT) were performed with penicilloyl-poly-lysine (PPL), minor determinant (MD), and clavulanic acid at commercially available concentrations (Diater), as well as with penicillin $\mathrm{G}$ (10 $000 \mathrm{IU} / \mathrm{mL})$, amoxicillin $(20 \mathrm{mg} / \mathrm{mL})$, amoxicillinclavulanic acid $(20 / 4 \mathrm{mg} / \mathrm{mL})$, cefuroxime $(2 \mathrm{mg} / \mathrm{mL})$, ceftazidime $(2 \mathrm{mg} / \mathrm{mL})$, and meropenem $(1 \mathrm{mg} / \mathrm{mL})$. The results of the skin tests were negative, and the patient underwent a drug provocation test (DPT) with amoxicillinclavulanic acid. Two and a half hours after receiving a therapeutic dose of 500/125 mg (cumulative dose, amoxicillin $875 \mathrm{mg} /$ clavulanic acid $218.75 \mathrm{mg}$ ), he experienced epigastric pain, dizziness, and nausea and vomited once. A bolus of physiological saline solution, ranitidine, and ondansetron were administered intravenously, with complete resolution of symptoms in 2.5 hours.

Metamizole was assessed on a different day. SPT at $400 \mathrm{mg} / \mathrm{mL}$ and IDT at 4 and $10 \mathrm{mg} / \mathrm{mL}$ yielded negative results, and the patient underwent DPT with metamizole, which was well tolerated.

Given the suspicion that the digestive symptoms during the DPT with amoxicillin-clavulanic acid were nonspecific, SPT and IDT were repeated for ß-lactams 3 weeks later. Once again, the results were negative. DPT was performed with amoxicillinclavulanic acid. One and a half hours after receiving a therapeutic dose of 500/125 mg, the patient experienced abdominal pain, profuse diarrhea, nausea, and repetitive vomiting. Two boluses of physiological saline, ranitidine ( $50 \mathrm{mg})$, ondansetron ( $8 \mathrm{mg})$, and methylprednisolone $(60 \mathrm{mg})$ were administered intravenously. Loperamide (4 mg) was also given orally. The patient developed marked pallor and dizziness. His vital signs remained stable at all times. Three hours after the onset of symptoms, and despite all the medications given, profuse diarrhea persisted. A blood sample revealed no relevant abnormalities other than a hemoglobin concentration of $18 \mathrm{~g} / \mathrm{dL}$, which was consistent with dehydration secondary to loss of liquids. The patient was transferred to the emergency room, where he only received another bolus of physiological saline. His condition gradually improved, and he was discharged after 2.5 hours of observation.

A blood test performed at a follow-up visit 2 days later revealed hemoglobin $15.4 \mathrm{~g} / \mathrm{dL}$, tryptase $3.2 \mu \mathrm{g} / \mathrm{dL}$, negative serum specific IgE for amoxicillin, ampicillin, cefaclor, and penicillin $\mathrm{G}$ and $\mathrm{V}$, and total $\mathrm{IgE}$ of $496 \mathrm{kU} / \mathrm{L}$ (ImmunoCAP, Thermo Fisher Scientific). Analysis of stool samples taken 24 and 48 hours after the DPT with amoxicillinclavulanic acid were sent for determination of eosinophil cationic protein (ECP) and revealed 77.4 and $50 \mu \mathrm{g} \mathrm{ECP} / \mathrm{g}$ feces, respectively. Six weeks later, measurement of ECP in a further 2 stool samples taken on 2 different days yielded results of 1.8 and $2.1 \mu \mathrm{g} \mathrm{ECP/g}$ feces, respectively.

Finally, in order to rule-out cross reactivity with other ß-lactams, a DPT was performed with penicillin $\mathrm{V}$ and $\mathrm{G}$, both of which were well tolerated.

DIES is an uncommon and probably underreported nonIgE-mediated hypersensitivity reaction provoked by drugs. Its clinical presentation is very similar to that of food proteininduced enterocolitis syndrome (FPIES) [1-5]. Extrapolating the criteria of the 2017 International Consensus Guidelines for FPIES [5] to the present case shows that the patient fulfils the major criterion (vomiting in the 1- to 4-hour period after ingestion of the suspected drug and absence of classic IgEmediated allergic skin or respiratory symptoms) and 5 of the 9 minor criteria (repetitive vomiting after ingestion of the same drug, marked pallor, need for emergency department visit, need for intravenous fluid support, and diarrhea in the 24 hours following ingestion of the suspected drug) [6]. Increased neutrophil count is a common finding after positive food challenge in FPIES and has also been described in 4 of the reported cases of DIES. Neutrophils usually peak 6 hours after ingestion of the trigger [6]. In the present case, the patient's blood was collected 3 hours after taking a therapeutic dose, possibly prior to the peak.

To our knowledge, out of the few cases of DIES reported [1-5], this is the second to involve amoxicillinclavulanic acid [3]. DPT was carried out successfully with penicillin in only 2 of the published cases $[2,5]$ and with cefpodoxime in 1 [5]. We confirmed that the patient tolerated penicillin, thus enabling us to prohibit only aminopenicillins and cephalosporins with the same side chain as amoxicillin (cefaclor, cefalexin, cefadroxil, and cefprozil) and to allow all other B-lactam antibiotics.

In all of the reported cases, the DPT was performed close in time to the initial reaction, although in the case we 
report, there was a 9-year interval between the first reaction and the positive DPT. In FPIES, periodic re-evaluations are recommended to assess whether the patient is still reactive. Rates of resolution of FPIES vary considerably, although many resolve after a few years [6]. While we do not know whether this applies to DIES, persistence over time was observed in the present case.

It is noteworthy that all the reported cases of DIES involve amoxicillin with or without clavulanic acid [1-5]. Compared with penicillin, these drugs increase the motility of the small intestine [9] and are associated with a higher frequency of gastrointestinal adverse effects, including diarrhea [10]. However, the gastrointestinal symptoms reported in the present case are suggestive of DIES with a specific underlying immune mechanism. This is supported by the fact that onset was after intake of the first therapeutic dose, the severity of the reaction, and the presence of elevated ECP in stool. These findings are consistent with the activation of eosinophils in FPIES reported elsewhere $[7,8]$.

In summary, we report a case of DIES induced by amoxicillin-clavulanic acid in an adult patient with good tolerance to penicillin. Assessing tolerance to penicillin is important in the management of such uncommon cases in order to avoid unnecessary restrictions of all ß-lactam antibiotics.

\section{Funding}

This study was supported by Instituto de Salud Carlos III (ISCIII) and cofunded by Fondo Europeo de Desarrollo Regional - FEDER for the ARADyAL research network (RD16/0006/0009).

\section{Conflicts of Interest}

Dr. Sánchez-Morillas reports personal fees from Sociedad Madrid-Castilla La Mancha de Alergología e Inmunología Clínica and from Alk-Abelló outside the submitted work.

Dr. González-Gutiérrez reports personal fees from Sociedad Madrid-Castilla La Mancha de Alergología e Inmunología Clínica and from GSK and Teva outside the submitted work.

Dr. Cimarra reports personal fees from Sociedad MadridCastilla La Mancha de Alergología e Inmunología Clínica and from Novartis and ALK outside the submitted work.

Dr. Cerecedo reports consultancy fees from Diater, Leti, ALK, and Stallergenes outside the submitted work and personal fees from Sociedad Madrid-Castilla La Mancha de Alergología e Inmunología Clínica, and grants from the Spanish Government (ISCIII). Dr. Cerecedo holds a patent (PCT/ES2014/070634).

Dr. Fernández-Rivas reports grant from the European Commission and the Spanish Government (MINECO, ISCIII) and personal fees from Aimmune, ALK-Abelló, Allergy Therapeutics, Fundación SEAIC, HAL, Thermo Fisher Scientific, Schreiber Foods, and DBV outside the submitted work. Dr. Fernández-Rivas also holds a patent (PCT/ES2014/070634).

The remaining authors declare that they have no conflicts of interest.

\section{Previous Presentation}

This case report was presented as a poster at the International Symposium "Avances y Perspectivas en Alergia Cutánea e Inmunología" organized by the SEAIC in Gran Canaria, Spain, October 23-26, 2019.

\section{References}

1. Novembre E, Mori F, Barni S, Pucci N. Drug-Induced Enterocolitis Syndrome (DIES). Pediatr Allergy Immunol. 2014:4:415-6.

2. Infante S, Zapatero L. Drug-induced enterocolitis syndrome by amoxicillin. Pediatr Allergy Immunol. 2017;1:105-6.

3. García Rodríguez R, Alfaya Arias T, Borja Segade J, Méndez Díaz Y, Moreno Lozano L, Extremera Ortega A, et al. Druginduced enterocolitis in an adult patient. J Allergy Clin Immunol Pract. 2017;6:1752-3.

4. Van Thuijl AOJ, Landzaat LJ, Liem O, Emons JAM, Arends NJT. Drug Induced Enterocolitis Syndrome (DIES): a clinical entity which deserves more awareness. Ann Allergy Asthma Immunol. 2019;122:538-9.

5. Worcel J, Tarelho M, Baron M, Ponvert C, Bidat E, Benoist G, et al. Drug-Induced enterocolitis syndrome (DIES) in a 10-yearold girl. Arch Pediatr. 2020;1:51-2.

6. Nowak-Wegrzyn A, Chehade M, Groetch ME, Spergel JM, Wood RA, Allen K, et al. International consensus guidelines for the diagnosis and management of food protein-induced enterocolitis syndrome: Executive summary- Work group Report of the Adverse Reactions to Foods Committee, American Academy of Allergy, Asthma\&Immunology. J Allergy Clin Immunol. 2017;139:1111-26.

7. Goswami R, Blazquez AB, Kosoy R, Rahman A, NowakWegrzyn $A$, Berin MC. Systemic innate immune activation in food protein-induced enterocolitis syndrome. J Allergy Clin Immunol. 2017;139:1885-96.

8. Berin MC. Immunopathophysiology of Food ProteinInduced Enterocolitis Syndrome. J Allergy Clin Immunol. 2015;135:1108-13.

9. Caron F, Ducrotte P, Lerebours E, Colin R, Humbert G, Denis P. Effects of Amoxicillin-Clavulanate Combination of the motility of the Small Intestine in Human Beings. Antimicrob Agents Chemother. 1991;35:1085-8.

10. Gillies M, Ranakusuma A, Hoffmann T, Thoming S, McGuire T, Glasziou $P$, et al. Common harms from amoxicillin: a systematic review and meta-analysis of randomized placebocontrolled trials for any indication. CMAJ. 2015;187:E21-E31.

Manuscript received December 5, 2019; accepted for publication February 18, 2020.

Montserrat Fernández-Rivas

Servicio de Alergia, Hospital Clínico San Carlos

Prof. Martín Lagos, s/n

28040 Madrid, Spain

E-mail: mariamontserrat.fernandez@salud.madrid.org 